\title{
BIMBINGAN KONSELING KARIR DALAM PENDEKATAN SPRITUAL
}

\author{
Sisra Zeni \\ Program Studi Bimbingan Konseling, Jurusan Tarbiyah STAIN Batusangkar \\ Korespondensi: J1. Sudirman No. 137 Kubu Rajo Lima Kaum Batusangkar \\ e-mail: esista@gmail.com
}

\begin{abstract}
Spritual aspect is an important component in starting a work because it correlates with work etiquette itself. This research is aimed to describe of how teaching in Islam concept about a work, guidances and councelling carrier, even doing spritual approaching in councelling carrier. Actually, moslem people were very lucky because all guidances have been stated clear. They just translate and apprecite them in daily, weekly, and mothly activities. Whatever and whenever these activies were done, they cannot saparate them from spritual aspect.
\end{abstract}

Kata kunci: konseling, karir, spritual

\section{PENDAHULUAN}

A spek spritual telah mendapat perhatian sekitar tahun 1990-an. Banyak artikel dan buku yang berkaitan dengan peranan spritual dan agama dalam konseling karir. Aspek spritual merupakan komponen yang penting dalam aspek memulai suatu pekerjaan dan karir, karena menyangkut akhlak dalam pekerjaan. Untuk bisa menimbang bagaimana akhlak seseorang dalam bekerja sangat tergantung dari cara melihat arti kerja, cara kerja dan hakikat kerja. Dalam Islam, kerja merupakan bagian dari amalan yang tak lepas dari kaitan iman seseorang. Idealnya, semakin tinggi iman itu maka semangat kerjanya juga tidak rendah.

Umat Islam termasuk beruntung karena semua pedoman dan panduan sudah terkodifikasi. Kini tinggal bagaimana menterjemahkan dan mengapresiasikannya dalam kegiatan harian, mingguan dan bulanan. Jika di pandang dari sudut tujuan hidup yaitu mencari keridhaan Allah SWT maka apapun yang dikerjakan, di rumah, di kantor, di ruang kelas, di perpustakaan, di ruang penelitian ataupun dalam kegiatan kemasyarakatan, takkan lepas dari kerangka tersebut.

Artinya, setiap pekerjaan yang di lakukan, harus sadar dalam kerangka pencapaian Ridha Allah. Cara seperti seperti ini akan memberi dampak, dalam kesungguhan menghadapi pekerjaan. Jika seseorang sudah meyakini bahwa Allah SWT sebagai tujuan akhir hidupnya maka apa yang dilakukannya di dunia tidak akan dijalankan dengan sembarangan. Ia akan mencari kesempurnaan dalam mendekati kepada $\mathrm{Al}$ Haq. Ia akan mengoptimalkan seluruh kapasitas dan kemampuan inderawi yang berada pada dirinya dalam rangka mengaktualisasikan tujuan kehidupannya. Dalam bekerja ia akan sungguhsungguh (profesional) karena bagi dirinya bekerja tak lain adalah ibadah sebagai, pengabdian kepada Yang Maha 
Suci. Sebagaimana firman Allah dalam (Q.S At-taubah, 9: 105) yang artinya.

Dan katakanlah: "Bekerjalah kamu, maka Allah dan Rasul-Nya serta orangorang mukmin akan melihat pekerjaanmu itu, dan kamu akan dikembalikan kepada (Allah) Yang mengetahui akan yang gaib dan yang nyata, lalu diberitakan-Nya kepada kamu apa yang telah kamu kerjakan" (QS At-Taubah, 9: 105)

Memang, bila "kerja" dibatasi maknanya pada matra ekonomi dan sosial belaka, seakan-akan mengesankan adanya dikotomi antara yang profanduniawi (pasar, kerja) dengan yang sakral-ukhrawi (masjid, belajar). Celakanya, kesan seperti itu tampak begitu kuat di kalangan Muslim sendiri. Dalam realitanya, cakrawala pandang kaum Muslim modern atas dunia kehidupannya terbagi pada dua kelompok yakni, pertama, kelompok yang lebih terfokus pada urusan "pekerjaan". Mereka sudah mencoba menampilkan kinerja yang profesional, tapi motivasi bekerjanya sangat rapuh, yakni sekadar mencari uang semata. Akibatnya, dari motivasi yang kurang lurus tersebut, keinginannya untuk berderma di jalan Allah amat minim. Ia merasa tidak pantas untuk mengeluarkan sedekah, infak, zakat ataupun khumus karena toh yang bekerja adalah dirinya sendiri, bukan orang lain. Ia merasa bahwa kekayaan yang ia raih bukanlah anugrah dari Allah, namun dari jerih payahnya sendiri. Jadi, dalam mencari nafkah, mereka begitu punya semangat yang tinggi dan etos yang kuat. Akan tetapi, untuk urusan ilmu atau belajar mereka mencukupkan diri dengan pengetahuan yang sudah terakumulasi sebelumnya.

Kelompok kedua adalah mereka yang memfokuskan diri pada urusan keilmuan/"ibadah". Kelompok ini amat gandrung pada urusan yang sifatnya "intelektual-ritual", namun kurang bisa menampilkan sikap yang profesional dalam bekerja. Artinya, pekerjaan yang mereka tunaikan kualitasnya amat rendah, tidak tepat waktu, dan kurang cita rasa seni. Yang penting, selesai bung! adalah motto mereka. Dalam mengejar ilmu atau melakukan ibadah ritual, mereka memang "jago"-nya. Namun dalam urusan pekerjaan, mereka tidak punya sikap yang sama. Itu kan duniawi, kilah mereka.

Tafsir sosiologis dari Kunto tentang "pasar" dan "masjid" tampaknya mendekati kenyataan yang menimpa pada kaum Muslimin sendiri. Ideologi "kaum pasar" semakin diperkuat dengan serbuan pandangan materialisme barat yang sangat memuja benda atau materi. Materilah yang menjadi standar apakah orang ini pantas atau tidak untuk dihormati, dihargai, atau diakrabi, bahkan dikawini. Andil budaya massa seperti televisi, majalah, koran, ataupun radio semakin memperteguh lagi akan pandangan dunia yang sebetulnya asing, dan tidak berakar pada nadi kehidupan kaum Muslim.

Setiap orang selalu mendambakan agar karirnya selalu meningkat dari waktu ke waktu. Entah apapun bidang usaha dan pekerjaannya semua memiliki keinginan yang sama. Pelaku wirausaha menginginkan usahanya selalu menunjukkan kemajuan, karyawan perusahaan juga menginginkan karirnya meningkat bahkan melejit. Tanpa disadari terkadang terlena pada kemajuan usaha dan karir seseorang dan meratapi karir dan usaha yang tidak kunjung membaik.

Pikiran dan tindakan ini lazim terjadi hingga membelenggu dan sulit untuk bangkit dari keterpurukan dan kemandegan karir. Alih-alih ingin maju tetapi justru frustasi karena tidak kunjung sukses dalam karir. Karena itu agar sukses dalam berbisnis ataupun menekuni karir perlu dilakukan perubahan dalam diri, jika menginginkan 
hasil yang berbeda maka cara bertindakpun harus berbeda.

Sukses dan prestasi setiap individu sangat ditentukan oleh kemampuan setiap diri dalam memerankan diri dalam kesuksesan tersebut. Jika meminjam istilah Pak Ciputra kemampuan untuk mengubah kotoran dan rongsokan menjadi emas, tidak bisa tidak ditentukan oleh setiap individu masing-masing.

\section{PENDEKATAN SPRITUAL}

Sesungguhnya dikotomi antara "kerja" dengan "belajar" tidak perlu terjadi. Karena, apabila di hayati ikrar secara mendalam pada proposisi "Iyyaka na'budu wa iyyaka nasta'in" dalam surat Al-Fatihah, maka dunia kehidupan kaum Muslimin bernuansa ibadah yang sangat kental. Dalam firman-Nya yang lain, Allah mengatakan, "Dan tidaklah Aku ciptakan jin dan manusia, melainkan untuk beribadah," (QS Adz-Dzariyat, 51: 56). Sehingga, jelas-jelas tidak ada pemisahan antara yang sakral dengan yang profan, yang duniawi dengan yang ukhrawi.

Ketika mengomentari ayat, "Hai orang-orang yang beriman, penuhilah aqad-aqad (perjanjian) itu" (QS AlMa'idah, 5: 1), Raghib Isfahani, sebagaimana dikutip Seyyed Hossein Nasr (1994) mengatakan bahwa perjanjianperjanjian itu meliputi perjanjianperjanjian antara Tuhan dan manusia, yakni kewajiban-kewajiban manusia kepada Tuhan; perjanjian antara manusia dan dirinya sendiri; dan [perjanjian] antara individu dan sesamanya.

Dengan demikian, perjanjian (uqud) yang dirujuk pada ayat tersebut berkisar antara pelaksanaan shalat sehari-hari sampai menjual barang dagangan di bazaar, dari sembah sujud hingga kerja mencari penghidupan.
Konon, praktik shalat wajib di kalangan Syi'ah yang mencakup shalat fajr, shalat siang hari (Zhuhur dan 'Ashar), dan shalat malam hari (Maghrib dan 'Isya), merupakan refleksi etos kerja mereka yang begitu tinggi dan manifestasi produktivitas dalam berkarya. Artinya, bila kaum Syi'ah selesai melaksanakan shalat siang hari, maka setelah selesai shalat dan zikir, mereka akan kembali bekerja dengan semangat yang tetap terjaga.

"Kerja berkaitan erat dengan doa dan hidayah bagi semua masyarakat tradisional dan kaitan ini dirasakan dan diaksentuasikan dalam Islam," tulis Nasr (1994). Dengan mengamati lafaz adzan Syi'ah, dengan formulasi hayya 'ala alshalah, hayya 'ala al-falah, dan hayya 'ala khair al-'amal, Nasr menyimpulkan bahwa shalat dan kerja memiliki keterkaitan yang prinsipal. "Di sana hubungan antara shalat, kerja, dan amal saleh selalu ditekankan," lanjutnya.

Perspektif Islam yang padu, menolak membedakan antara yang sakral dan yang profan, yang ukhrawi dan yang duniawi, yang religius dan yang sekular atau, secara lebih spesifik, antara shalat dan kerja. Implikasi praktisnya adalah bahwa sebagaimana kita mencoba khusyu dalam shalat, maka begitu pula dalam bekerja kita mencoba untuk meng-khusyu'-kan diri.

Dalam bahasa bisnisnya, berusaha bersikap lebih profesional, lebih jauh, sebagaimana ketakutan pada Tuhan dan tanggung jawab kepada-Nya dalam meekspresi shalat, maka demikian pula dalam pekerjaan.

\section{KONSELING KARIR}

Konseling merupakan layanan bantuan yang ditujukan untuk meningkatkan pemahaman individu akan potensi dirinya untuk memecahkan 
masalah. Tolbert pada Prayitno (1993) merumuskan pengertian konseling:

Konseling karir menurut Drummond \& Ryan (1995):

Career conseling and development are processes in which counseling activities, strategic and interventtions are used to work with people who seek help ini making career exploration, planning and transition decisions.......in learning and working process.

Konseling adalah hubungan antar pribadi yang dilakukan secara tatap muka antara konselor yang memiliki kemampuan dan konseli yang membutuhkan pemecahan masalah dan menemukan kebutuhan-kebutuhan masa depannya.

Berdasarkan pendapat di atas dapat disimpulkan bahwa konseling merupakan proses hubungan antara konselor dan konseli yang terarah pada tercapainya tujuan tertentu yaitu pemecahan masalah. Untuk mencapai tujuan dalam upaya membantu, konselor menggunakan keahlian yang terlatih (kompetensi) untuk memahami berbagai permasalahan yang dihadapi konseli dan pemahaman terhadap berbagai karakteristik dan potensi yang dimiliki konseli.

Karir Jhon Dillard (dalam Hardiani Irman 2009:12) menyatakan bahwa karir menunjukan pada perlunya pelatihan training dan komitmen. Horby (dalam Hardiani Irman 2009:13) menyatakan karir adalah urutan okupasi dan pekerjaan utama (mayor) yang diselenggrakan atau digeluti seseorang dalam dan selama hidupnya, merupakan panggilan hidup dan memberikan kepuasan bagi diri yang bersangkutan. Menurut Susan Sears (dalam Dewa Ketut Sukardi 1989:19) karir adalah seluruh pekerjaan yang dikerjakan sepanjang hidup (seumur hidup) contoh: guru, pegawai, Dokter.

Menurut A. Muri Yusuf (dalam Hardiani Irman 2009:13) occupation (jabatan) adalah sekumpulan pekerjaan yang mempunyai tugas-tugas yang sama atau saling berhubungan, membutuhkan kecakapan, pengetahuan dan keterampilan yang sama pula dalam organisasi/lembaga yang berbeda, bersifat ekonomis, berorientasi tugas dan masyarakat/society. Contoh: Akuntansi, Sekretaris, auditing.

Pekerjaan Menurut Susan sears (dalam Dewa Ketut Sukardi 1989:19) pekerjaan adalah suatu kelompok posisi yang serupa yang memerlukan beberapa perlengkapan serupa dalam suatu organisasi tunggal, contoh: berdagang. Abdul hamid Nursi (1997: 20) menya takan job analysis adalah usaha untuk mencari tahu tentang jabatan atau pekerjaan yang berkaitan dengan tugas-tugas yang dilakukan dalam suatu jabatan. Menurut Libertus Jehani (2008: 96) job analysis adalah merumuskan jabatan baik tenaga pelaksanaan, non manajerial maupun manajerial dalam suatu perusahaan. Contoh: PS (Pemeriksa Sekolah)

Menurut Teori trait and faktor dikembangkan oleh Frank Parsons berawal pada akhir abab ke-19. Frank person mulai mencari suatu cara untuk membantu anak-anak remaja yang memiliki kesulitan dan permasalahan dalam memilih suatu bidang pekerjaan yang sesuai dengan potensi, bakat, minat yang dimiliki mereka.

Awal abab ke 20 konseling karir yang bersumber pada gerakan bimbingan jabatan, mendapat tempat yang makin baik di Amerika Serikat. Berdasarkan ini tidak salah kiranya Frank paeson disebut sebagai bapaknya konseling karir pada masanya dan juga sampai sekarang ini karena ide-ide yang berlian yang dilahirkannya menjadi peletak lahirnya konseling karir yang sampai saat ini terus mengalami perkembangan.

Pengertian Teori Trait and Faktor secara bahasa trait diartikan sebagi sifat, karakteristik seorang individu, sedangkan faktor berarti tipe-tipe, syarat-syarat tertentu yang dimiliki oleh sebuah 
pekerjaan atau suatu jabatan.Asumsi teori trait and factor menurut Miller (dalam Manhiru 1992: 65) ada beberapa asumsi yang mendasari lahirnya teori trait and faktor. Asumsi-asumsi tersebut diantaranya:

* Perkembangan vokasional sebahagian besar merupakan suatu proses kognitif, keputusan-keputusan dicapai melalui penalarannya.

* Pilihan okupasional merupakan sesuatu yang tunggal. Berdasarkan pengaruh Parson, pilihan diberikan penekanan yang terbesar dan perkembangan diberi penekanan yang sangat kecil.

* Kekuatan dan kelemahan teori trait and faktor:

Kekuatan teori trait and factor adalah:

- Klien mendapatkan data yang akurat dan falid tentang dirinya, yang diperoleh melalui berbagai tes psikologi dan non tes psikologi dan non tes yang dikerjakan oleh konselor secara ilmiah.

- Klien mendapatkan berbagai informasi dunia kerja dan berbagai informasi dunia kerja dan berbagai persyaratan yang mesti dimiliki untuk memasuki dunia kerja tersebut.

- Klien mendapatkan berbagai tawaran terhadap pilihan pekerjaan, kepuasan karir dan solusi terhadap berbagai persoalan yang dihadapinya.

- Klien akan lebih puas apabila mendapatkan karir sesuai dengan analisis sifat dan faktor. Kemungkinan tingkat keberhasilan dan kesuksesan dalam menggeluti karir akan lebih tinggi.

Kelemahan teori trait and factor adalah:

- Klien lebih bersifat pasif dan yang lebigh aktif itu adalah guru pembimbing (konselor).
- Klien akan frustasi apbila pilihan karir tidak dapat ia temukan, karena klien terbatas pada pilihan karir yang telah ditetapkan oleh konselor berdasarkan analisa sifat dan faktor.

- Dalam konseling yang lebih tahu tentang diri klien adalah klien itu sendiri, tugas dari konselor adalah menemukan diri klien dan melahirkan kemandirian yang sesungguhnya, sementara dalam konseling trait and faktor ini sebaliknya.

Dalam pandangan Ginzberg. Teori ini lahir merupakan usaha bersama para ahli yang terdiri dari seorang ekonom , seorang psikiater, seorang sosiolog, dan seorang psikolog, diantara mereka adalah Ginzberg, Ginburg, Axelrad, dan Herma (1951), mereka inilah yang memberi pandangan bahwa pemilihan karir adalah suatu proses yang terbuka sepanjang waktu. Ginzberg (dalam Hadiarni, Irman 2009: 122) menyatakan bahwa pilihan jabatan tidak hanya terjadi sekali saja, melainkan mengalami proses perkembangan yang meliputi jangka waktu antara 6-15 tahun.

Adapun yang menjadi dasar pandangan Ginzberg (dalam Manrihu, 1992: 88-89) tentang pilihan okupasional adalah sebagai berikut:

* Pilihan okupasional adalah suatu proses perkembangan yang secara khas berlangsung sepanjang periode umur 10 sampai 15 tahun.

* Proses itu sebagian besar tidak dapat diubah.

* Pilihan okupasional berakhir dalam suatu kompromi antara minatminat, kapasitas-kapasitas, nilainilai, dan kesempatan-kesempatan.

* Ada tiga periode pilihan okupasional fantasi, tentatif, dan realistik. 
Faktor-faktor yang mempengaruhi pilihan okupasional seseorang adalah nilai-nilai individu, faktorfaktor emosional, taraf dan jenis pendidikan, serta dampak realitas melalui tekanan-tekanan lingkungan.

Ginzberg (dalam Munandir 1996: 92) menyatakan bahwa pilihan pekerjaan merupakan proses pengambilan keputusan yang berlangsung sepanjang hayat bagi mereka yang mencari banyak kepuasan dari pekerjaannya, ini mengharuskan mereka berulang-ulang melakukan penilaian kembali, dengan maksud mereka lebih dapat mencocokan tujuan-tujuan karir yang terus berubahrubah dengan dunia kerja.

Ketiga kebutuhan-kebutuhan manusia dapat mempengaruhi pilihan karir seseorang, hal ini berkaitan dengan teori kebutuhan yang dikembangkan oleh Maslow (dalam Hadiarni Irman 2009: 113). Hanya dikembangkan secara sempit, hanya menekan salah satu aspek saja. Misalnya: aspek pemusatan pada konsep diri, dan aspek pemusatan pada kebutuhan.

\section{TUJUAN KONSELING KARIR}

Dalam kaitannya dengan perjalanan karir, kegiatan konseling memiliki dua peran utama, yaitu dalam arti luas dan tujuan yang spesifik. Kegiatan konseling itu sendiri akan membantu seseorang untuk mengatasi masalahmasalah yang dapat mengganjal seseorang mencapai performansi prima. Performansi yang prima ini akan memuluskan perjalanan karir seseorang. Jadi peran konseling dalam arti luas akan menjadi fasilitator bagi perkembangan karir seseorang. Kemudian dalam arti spesifik, adalah konseling karir yang bertujuan untuk membantu seseorang mengambil keputusan berkaitan dengan pilihan-pilihan karir.
Konseling merupakan suatu proses yang dilaksanakan secara pribadi dan konfidensial untuk membantu anak buah dalam menyelesaikan masalah yang dihadapi. Sesuai dengan tujuannya sebagai upaya pencegahan atau penyelesaian masalah, konseling dapat kita kategorikan menjadi konseling proaktif dan konseling reaktif. Dalam proses konseling proaktif, konselor perlu memainkan peran yang lebih aktif bila dibandingkan dengan perannya dalam proses konseling reaktif. Kedua pendekatan ini perlu secara berkesinambungan dilaksanakan dan dievaluasi, agar dapat memberikan hasil nyata sebagai katalisator peningkatan performansi.

Sedangkan kesadaran bekerja akan melahirkan suatu perbaikan (improvement) untuk meraih nilai yang lebih bermakna, dia mampu menuangkan idenya dalam bentuk perencanaan, tindakan, serta melakukan penilaian dan analisa tentang sebab dan akibat dari aktivitas yang dilakukan (managerial aspect).

Dengan cara pandang seperti ini, sadarlah bahwa setiap muslim tidaklah akan bekerja hanya sekedar untuk bekerja; asal mendapat gaji, dapat surat pengangkatan atau sekedar menjaga gengsi supaya tidak disebut sebagai penganggur. Karena, kesadaran bekerja secara produktif serta dilandasi semangat tauhid dan tanggung jawab uluhiyah merupakan salah satu ciri yang khas dari karakter atau kepribadian seorang muslim.

Ajaran sunnah yang mangatakan "tangan di atas lebih mulia dari pada tangan di bawah", seakan-akan menghantui dirinya, menggedor dan menggapai-gapai untuk selalu tampil sebagai subyek yang terbaik. Dia tidak akan merasa nista apabila dalam hidupnya tak mampu memberikan makna pada lingkungannya, bahkan dia merasa tak berharga apabila harus hidup sebagai 
benalu yang hidupnya statis apalagi harus menjadi peminta-minta. Terkenanglah dia akan ucapan Nabiyullah Muhammad SAW yang bersabda:

$$
\begin{aligned}
& \text { وعن ابى هر يرة رضالله عنه قال رسول الله صلى } \\
& \text { الله عليه وسلم لان يحتطب احدكم حزمة على } \\
& \text { ظهره خيرله من ان يسال احدا فيعطيه او يمنعه } \\
& \text { (متفق عليه) }
\end{aligned}
$$

"Andainya seseorang mencari kayu bakar dan dipikulkan di atas punggungnya, hal itu lebih baik dari pada kalau ia meminta-minta pada seseorang yang kadang-kadang diberi, kadang pula ditolak". (Diriwayatkan oleh Bukhori dan Muslim)

Setiap muslim menyadari bahwa dirinya hanya berharga apabila ia berkarya, mencipta dan mampu memberikan arti pada lingkungannya. Maka terkenanglah dirinya akan nasehat sabda suci Rasulullah SAW yang mengatakan:

$$
\text { المؤمن القوي خير واحب الى الله من المؤمن }
$$

"Bahwa mukmin yang kuat itu lebih baik dan lebih dicintai Allah dari pada mukmin yang lemah".

Yang perlu kita cermati bersama adalah seringnya menempatkan fungsi konseling pada departemen sumber daya manusia saja. Sebenarnya, fungsi konseling memang terkait erat dengan program yang dijalankan oleh departemen SDM, tetapi sebenarnya semua pimpinan wajib untuk memahami dan melaksanakan kegiatan konseling bagi anak buahnya. Adalah sesuatu yang manusiawi bahwa bawahan memiliki problema kehidupan, berkaitan dengan lingkungan pekerjaannya, maupun dalam kehidupan sehari-hari.
Sebagai agama yang bertujuan mengantarkan hidup manusia kepada kesejahteraan dunia dan akhirat, lahir dan bathin, Islam telah membentangkan dan merentangkan pola hidup yang ideal dan praktis. Pola hidup Islami tersebut dengan jelas dalam Alqur'an dan terurai dengan sempurna dalam sunnah Rasulullah SAW. Itulah sebabnya, penghargaan Islam terhadap budaya kerja bukan hanya sekedar pajangan alegoris, penghias retorika, pemanis bahan pidato, indah dalam pernyataan tetapi kosong dalam kenyataan.

Islam membuka pintu kerja setiap muslim agar ia dapat memilih amal yang sesuai dengan kemampuannya, pengalaman, dan pilihannya. Islam tidak membatasi suatu pekerjaan secara khusus kepada seseorang, kecuali demi pertimbangan kemaslahatan masyarakat. Islam tidak akan menutup peluang kerja bagi seseorang, kecuali bila pekerjaan itu akan merusak dirinya atau masyarakat secara fisik atau pun mental. Setiap pekerjaan yang merusak diharamkan oleh Allah.

Huizinga mengatakan bahwa manusia adalah homo ludens, yaitu pribadi yang bebas menentukan sikap dan memilih obyek dunia sebagai bahan kreatifitas dan permainan (ludens), maka muslim mengatakan bahwa manusia adalah khalifatullah, wakil Allah yang bebas menentukan pilihannya sesuai dengan kerangka Qur'ani dan sunnah, sehingga dirinya tampil untuk mempermainkan dunia, dan bukan sebaliknya dimana dunia mempermainkan dirinya karena setiap muslim sadar bahwa dirinya tidak mungkin tenggelam dalam arus permainan dunia (al-dunya la'ibun wa lahwun)

Terdapat beberapa alasan mengapa konseling harus dilakukan oleh atasan. Pertama, atasanlah yang paling berkepentingan terhadap performansi anak 
buah. Kedua, atasanlah yang dianggap paling tahu mengenai dinamika psikologis anak buah berkaitan dengan pelaksanaan tugas. Seorang atasan yang baik akan sangat care terhadap anak buahnya, dan memiliki kepekaan yang tinggi, jika anak buahnya mengalami suatu masalah yang mengganggu performansinya. Ketiga, kegiatan konseling juga dapat dimanfaatkan oleh atasan bukan saja hanya untuk tujuan kuratif, tetapi juga dapat digunakan untuk tujuan pengembangan bawahan. Misalnya untuk memotivasi bawahan agar dapat berprestasi lebih baik atau untuk menciptakan suasana psikologis yang kondusif agar bawahan betah dalam rangka retaining bawahan.

Agar dapat menjalankan fungsi sebagai konselor efektif, kita perlu mengembangkan secara intensif kemampuan untuk mendengarkan secara aktif, dalam artian mampu mendengar apa yang terucap dan tidak terucap. Seorang konselor perlu memiliki derajat sensitivitas yang relatif tinggi terhadap sikap yang ditunjukkan dan perubahanperubahan yang ditunjukkan oleh anak buah selama proses berlangsung. Dengan kata lain, kita perlu menjadi seorang intervener yang taktis dan adaptif.

Yang juga perlu disadari adalah komitmen kita dalam menjadi seorang konselor. Konseling bertujuan untuk membantu, bukan bertujuan untuk mengambil alih persoalan anak buah dengan cara menjadi judge atau pengambil keputusan. Sebaiknya kita mengambil pendekatan lain, dengan melaksanakan peran sebagai fasilitator, pemberi arahan, penasehat dan sebagai teman. Peran yang terakhir ini amat penting karena konseling hanya dapat berjalan dengan baik apabila konselor dianggap sebagai "teman" yang dapat dipercaya.

Manajer sebagai konselor perlu pula membatasi diri, dalam artian memahami benar kapan suatu proses konseling perlu diarahkan ke bantuan secara profesional. Ketidakmampuan untuk mendeteksi kebutuhan ini atau penundaan terhadap kebutuhan professional help akan secara signifikan merugikan pengembangan anak buah dan dapat menimbulkan dampak negatif bagi perusahaan. Dalam manajemen konseling kita perlu memperhatikan dua faktor utama, yaitu faktor waktu dan faktor isi.

Berdasarkan waktu pelaksanaannya, proses konseling biasanya dikategorikan menjadi proses konseling periodik dan konseling spesial. Konseling periodik dilaksanakan secara regular dalam periode waktu tertentu, sedangkan konseling spesial diadakan apabila problem yang dihadapi oleh karyawan memerlukan penyelesaian segera

Berkaitan dengan isi konseling, diperlukan suatu persiapan pelaksanaan yang terencana secara matang. Manajer sebagai konselor harus memiliki bekal yang cukup sebelum memasuki arena sesungguhnya. Beberapa elemen yang harus diperjelas antara lain adalah tujuan konseling, pemahaman karakter anak buah, kedalaman informasi yang perlu digali serta persiapan awal mengenai pengarahan yang akan diberikan. Dalam pelaksanaanya, proses konseling sering mendapat halangan dari pihak anak buah. Biasanya resistensi ini muncul karena adanya perasaan takut atau direndahkan. Yang terjadi kemudian bukan proses konseling sebenarnya tetapi proses konseling semu, karena anak buah akan lebih bersikap defensif atau diskonfirmasi. Sikap defensif biasanya menyebabkan anak buah menjadi lebih berfokus pada upaya melindungi diri sendiri dan tidak pada inti permasalahan sebenarnya. Sebaliknya, sikap diskonfirmasi menimbulkan suasana yang lebih agresif karena keinginan anak buah untuk memulihkan kehormatan dirinya. 
Untuk meminimalkan kemungkinan negatif ini dan untuk mendukung terciptanya suasana konseling yang efektif, kita sebagai manajer dan konselor memiliki tanggung jawab untuk dapat menghidupkan iklim yang tepat. Dalam hal ini perlu dibina terbentuknya komunikasi terbuka yang dilandasi oleh adanya emphaty dan trust. Selanjutnya, agar proses konseling dapat mengarah pada sasaran tepat dengan tingkat penerimaan yang tinggi, atmosfir konseling harus dilengkapi dengan kehadiran manajemen partisipasi dan pola kepemimpinan tipe transformasi.

Proses konseling sebaiknya dilaksanakan secara berkesinambungan oleh atasan. Melalui proses konseling atasan dapat lebih memahami sisi kehidupan bawahan secara utuh. Atasan akan mengetahui potensi, minat, kepribadian bawahan secara lebih baik. Pemahaman ini dapat mendukung pembentukan kerjasama kelompok yang lebih baik, mendukung kepemimpinan dan lebih mudah untuk memotivasi mereka.

\section{PENUTUP}

Pendekatan spiritual dalam bingan dan konseling karir adalah upaya membantu menumbuhkembangkan kembali kesadaran spiritual sesuai dengan fitrah manusia sebagai makhluk tauhid, agar terwujud cara membentuk sebuah karir dan bekerja berdasakan kepada alquran dan sunnah rasul. Oleh sebab itu pendekatan spiritual dalam bibmbingan dan konseling harus di bingkai dengan nuansa islami. Dikatakan nuansa islami karena dapat dilihat dari hal-hal berikut:

a. Landasan bimbigan dan konseling karir dalam pendekatan spiritual difokuskan dalam penerapan kesadaran bekerja akan melahirkan suatu perbaikan (improvement) untuk meraih nilai yang lebih bermakna, dia mampu menuangkan idenya dalam bentuk perencanaan, tindakan, serta melakukan penilaian dan analisa tentang sebab dan akibat dari aktivitas yang dilakukan (managerial aspect).

b. Proses bimbingan dan konseling harus sesuai dengan hakikat manusia kepada Maha pencipta. Ajaran sunnah yang mangatakan "tangan di atas lebih mulia dari pada tangan di bawah", seakan-akan menghantui dirinya, menggedor dan menggapai-gapai untuk selalu tampil sebagai subyek yang terbaik. Dia tidak akan merasa nista apabila dalam hidupnya tak mampu memberikan makna pada lingkungannya, bahkandia merasa tak berharga apabila harus hidup sebagai benalu yang hidupnya statis apalagi harus menjadi peminta-minta. Terkenanglah dia akan ucapan Nabiyullah Muhammad SAW yang bersabda:

$$
\begin{aligned}
& \text { وعن ابى هر يرة رضالله عنه قال رسول الله صلى } \\
& \text { الله عليه وسلم لان يحتطب احدكم حزمة على } \\
& \text { ظهره خيرله من ان يسال احدا فيعطيه او يمنعه } \\
& \text { (متفق عليه) }
\end{aligned}
$$

"Andainya seseorang mencari kayu bakar dan dipikulkan diatas punggungnya, hal itu lebih baik dari pada kalau ia meminta-minta pada seseorang yang kadang-kadang diberi, kadang pula ditolak". (Diriwayatkan oleh Bukhari dan Muslim) 


\section{DAFTAR RUJUKAN}

Alquran dan terjemahan, 2007. Bandung apt Syaamil Cipta media.

Najati Utsman, 2005. Psikologi Dalam Al-quran: Terapi Al-quran Dalam Pengembuhan gangguan jiwa. Bandung Pustaka Setia.

Dewa Ketut Sukatdi, 2004. Psikologi Pemilihan Karier. Rineka cipta
Manhiru, 1992. Pengantar Bimbingan dan Konseling Karier. Bumi Aksara

A Muri Yusuf, 2005. Kiat Sukses Dalam Karier. Ghalia Indonesia

Prayitno, 2003. Dasar-dasar Bim-bingan Dan Konseling. Rineka Cipta

Hadiarni, 2009. Konseling Karier. Stain Batusangkar Press 